\title{
THE OCCURRENCE OF AEROMONAS IN DRINKING WATER, TAP WATER AND THE PORSUK RIVER
}

\author{
Merih Kivanc $^{1}$, Meral Yilmaz ${ }^{1 *}$, Filiz Demir ${ }^{1}$ \\ Anadolu University, Faculty of Science, Department of Biology, Eskişehir, Turkey. \\ Submitted: April 01, 2010; Returned to authors for corrections: May 11, 2010; Approved: June 21, 2010.
}

\begin{abstract}
The occurrence of Aeromonas spp. in the Porsuk River, public drinking water and tap water in the City of Eskisehir (Turkey) was monitored. Fresh water samples were collected from several sampling sites during a period of one year. Total 102 typical colonies of Aeromonas spp. were submitted to biochemical tests for species differentiation and of 60 isolates were confirmed by biochemical tests. Further identifications of isolates were carried out first with the VITEK system (BioMerieux) and then selected isolates from different phenotypes (VITEK types) were identified using the DuPont Qualicon RiboPrinter® system. Aeromonas spp. was detected only in the samples from the Porsuk River. According to the results obtained with the VITEK system, our isolates were 13\% Aeromonas hydrophila, 37\% Aeromonas caviae, 35\% Pseudomonas putida, and 15\% Pseudomonas acidovorans. In addition Pseudomonas sp., Pseudomonas maltophila, Aeromonas salmonicida, Aeromonas hydrophila, and Aeromonas media species were determined using the RiboPrinter ${ }^{\circledR}$ system. The samples taken from the Porsuk River were found to contain very diverse Aeromonas populations that can pose a risk for the residents of the city. On the other hand, drinking water and tap water of the City are free from Aeromonas pathogens and seem to be reliable water sources for the community.
\end{abstract}

Key words: Aeromonas spp, drinking water, river water, tap water, Riboprinter

\section{INTRODUCTION}

The importance of detection of Aeromonas spp. has increased in recent years due to their emergent human pathogenic properties (9). Aeromonas spp. can cause septicaemia, wound infections $(10,18)$ and diarrhoeal illness (7).

Aeromonas are Gram-negative, oxidase-positive, facultative anaerobic, glucose fermenting, rod-shaped bacteria of the family Aeromonadaceae (8). Aeromonas spp. are common aquatic microorganisms that occur in irrigation water, river water, brackish water, freshwater, spring water, surface water and groundwater, estuarine and sea water, chlorinated and non-chlorinated drinking water $(5,6,12,13,24)$ and in some countries, in bottled mineral water (17). All phenospecies are found in sewage-contaminated water (2). The prevalence and distribution of Aeromonas in aquatic environments, its role as a contaminant for drinking water supplies and potential for pathogenicity mediated by mesophilic Aeromonas are all of great public health concern $(3,6)$.

Residents of the City of Eskisehir in Turkey use treated water not for drinking but for cleaning, washing, and various recreational purposes as tap water from the Porsuk River. Therefore, the safety of the treated water from the Porsuk River is very important for the residents of the City. Lack of information about the incidence of motile Aeromonas in

*Corresponding Author. Mailing address: Anadolu University, Faculty of Sciences, Department of Biology, Eskisehir-TURKEY.; Tel.: +90 222 335 05 80.; Email: meralyilmaz@ anadolu.edu.tr 
Eskisehir tap water and the Porsuk River as well as in drinking water should be great concern because their possible occurrence in such waters could be a potential source of infection for the residents.

In this study, the occurence of Aeromonas species in the Porsuk River, tap water obtained from the Porsuk River after treatment and drinking water of the City of Eskisehir was investigated.

\section{MATERIALS AND METHODS}

\section{Collection of Water Samples}

Samples were collected from 12 different sites on the Porsuk River at monthly intervals during the period of a year. Tap water samples were collected from houses, business centers and hospitals, randomly selected different parts of the City of Eskisehir. Drinking water samples sold in plastic bottles were purchased from a variety of retailers in the city.

Water samples from the river and tap water were brought to the laboratory in $500 \mathrm{ml}$ sterile glass bottles. In order to inactivate chlorine, sterile sodium thiosulphate solution was added $(13.2 \mathrm{mg} / \mathrm{l})$. The samples were immediately stored under ice-cold conditions and microbiological analyses were performed within $3 \mathrm{~h}$ of collection.

\section{Isolation and Identification of the Strains}

$10 \mathrm{ml}$ of water were inoculated in $90 \mathrm{ml}$ of peptone water with $1 \% \mathrm{NaCl}(\mathrm{w} / \mathrm{v})$ at $\mathrm{pH} 8.6$ adjusted with sodium hydroxide. After incubation at $37{ }^{\circ} \mathrm{C}$ for $24-48 \mathrm{~h}$, the cultures were streaked on Glutamate Starch Phenol Red agar (GSP) and incubated at $37{ }^{\circ} \mathrm{C}$ for $24-48 \mathrm{~h}$ (3). Colonies of presumptive Aeromonas spp. surrounded by yellow zone on GSP medium were purified and maintained on nutrient agar slants at $4{ }^{\circ} \mathrm{C}$ after subculturing several times. Their identifications were confirmed on the basis of the results of the following tests: Gram stain test, oxidase test, the oxidation/fermentation test, a test to determine the resistance to vibriostatic agent $\mathrm{O} / 129$. Additional tests (to detect gas production from glucose, growth in $\mathrm{KCN}$ broth, $\mathrm{H}_{2} \mathrm{~S}$ production from cysteine, esculin hydrolysis, and the suicide phenomenon) were performed for identification at the species level according to Bergey's Manual of Determinative Bacteriology 9th ed. (21). Motility was determined after $18 \mathrm{~h}$ in motility test medium (14). The production of hemolysin was assayed by recording the lysis of sheep erythrocytes in agar plates (5\% sheep blood in brain heart infusion agar). Plates were incubated aerobically for $48 \mathrm{~h}$ at $30^{\circ} \mathrm{C}$. All isolated strains were analyzed for their Cephalothin resistance according to the Kirby-Bauer test by using Mueller-Hinton agar.

Further identification of isolates which are possible Aeromonas spp. was performed with VITEK Gram-Negative Identification Panel (VITEK, BioMérieux). VITEK GNI cards were processed according to the manufacturer specifications. At least random two isolates from each VITEK profile type was further studied by the RiboPrinter Microbial Characterization System (Qualicon Inc., Wilmington, DE). Automated ribotyping was performed according to the manufacturer's protocol. To summarize, the automated process begins by lysing cells and cutting the released DNA into fragments with a restriction enzyme (EcoRI) and the restriction fragments were separated by electrophoresis and then transferred to a nylon membrane. Ribosomal DNA was hybridized to a chemiluminescent-labeled E. coli rRNA operon (rrnB) probe. The chemiluminescent patterns were electronically imaged and analyzed with the RiboPrinter Microbial Characterization System computer. The generated Riboprinter ${ }^{\circledR}$ patterns were analyzed with dendogram based on Unweighted Pair Group Method using arithmetic Averages (UPGMA) and Pearson correlation coefficients.

\section{RESULTS AND DISCUSSION}

In this study, we isolated a total number of 102 possible Aeromonas colonies from 144 Porsuk River, tap water and drinking water samples on the basis of morphological characters on the GSP agar. These isolates were characterized with physiological and conventional biochemical tests. According to the test results, only 60 typical Aeromonas 
isolates which all belong to the samples from the Porsuk River were determined and all positive isolates were Gram negative, motile, rod shaped and facultative anaerobes. The isolates were oxidase and catalase positive and did not tolerate $\mathrm{NaCl}$ concentrations higher than $3.0 \%$ (Table 1 ).

There is no reported study about the Riboprinter identification of Aeromonas isolated from water sources. In our study, VITEK and Riboprinter systems were employed to identify of Aeromonas isolates from water samples. A. hydrophila, A. caviae, Pseudomonas putida and Pseudomonas acidovorans strains were identified with biochemical tests and VITEK system. The number of A. hydrophila and A. caviae isolates obtained from different sites of the Porsuk River in different seasons in given in Table 2. These identification results are nearly concordant with those obtained with RiboPrinter Microbial Characterization System (Qualicon). Aeromonas and Pseudomonas genera were determined with the each system. Ribotyping profiles of some strains and standards are shown in Fig 1. In addition, the homology among the isolates was indicated using UPGMA.

Table 1. Biochemical characterization of Aeromonas and Pseudomonas spp. isolated from the Porsuk River

\section{Isolates}

\begin{tabular}{|c|c|c|c|}
\hline Tests & $\begin{array}{c}\text { Aeromonas hydrophila } \\
(8 \text { isolates })\end{array}$ & $\begin{array}{c}\text { Aeromonas caviae } \\
(22 \text { isolates })\end{array}$ & $\begin{array}{c}\text { Pseudomonas sp. } \\
\text { (30 isolates) }\end{array}$ \\
\hline Motility & + & + & + \\
\hline Oxidase & + & + & + \\
\hline Catalase & + & + & + \\
\hline $\mathrm{KCN}$ & + & + & + \\
\hline $\begin{array}{l}\mathrm{H}_{2} \mathrm{~S} \text { from gelatin cysteine } \\
\text { throsulfate }\end{array}$ & + & - & - \\
\hline Urea & - & - & - \\
\hline Voges-Proskauer & + & - & - \\
\hline Lysine decarboxylase & + & - & + \\
\hline Arginine dihydrolase & + & + & + \\
\hline Ornithine decarboxylase & - & - & + \\
\hline D-glucose (gas) & + & - & $\mathrm{v}$ \\
\hline D-Sorbitol & - & - & - \\
\hline Salicin & + & + & - \\
\hline Glycerol & + & + & + \\
\hline L-Arabinose & + & + & + \\
\hline Cellobiose & - & + & - \\
\hline Sucrose & + & + & - \\
\hline D-Trehalose & + & + & - \\
\hline Adonitol & - & - & - \\
\hline Citrate & + & + & + \\
\hline D-Mannitol & + & + & - \\
\hline Esculin hydrolysis & + & + & - \\
\hline Growth in $\mathrm{NaCl}$ & - & - & - \\
\hline $\mathrm{O} / 129(\mathrm{R})$ & + & + & + \\
\hline Cephalothin & $\mathrm{R}$ & $\mathrm{R}$ & $\mathrm{R}$ \\
\hline
\end{tabular}

\section{v: variable}

$\mathrm{R}$ : resistant 
Table 2. Aeromonas isolates obtained from different sites of the Porsuk River in different seasons in the city of Eskisehir

\begin{tabular}{ccc}
\hline & A. hydrophila & A. caviae \\
\hline Winter & 3 & 3 \\
Spring & - & 4 \\
Summer & - & 8 \\
Autumn & 5 & 7 \\
\hline
\end{tabular}

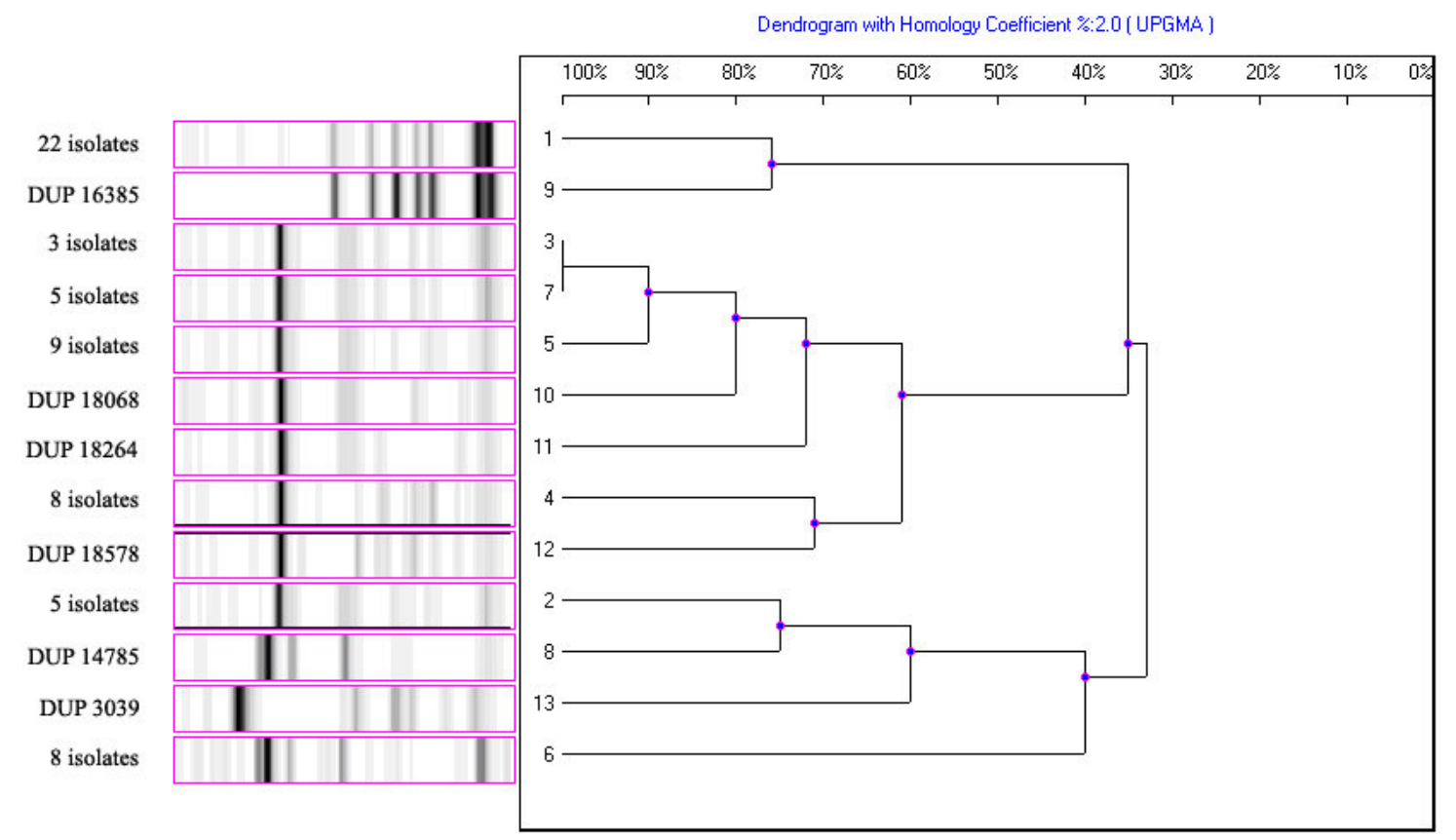

Figure 1. Ribotyping profiles of some isolates (1-7) and standards (8-13) placed the library of riboprinter system (DuPont)

1) Pseudomonas species ( $\mathrm{S}=0,96: \mathrm{RG}=\mathrm{ECORI-S}-1)$, 2) Aeromonas salmonicida $(\mathrm{S}=0,82: \mathrm{RG}=\mathrm{ECORI-S}-3)$, 3) Aeromonas hydrophila ( $\mathrm{S}=0,83: \mathrm{RG}=$ ECORI-S-4), 4) Aeromonas media $(\mathrm{S}=0,76: \mathrm{RG}=\mathrm{ECORI-S}-5)$, 5) Aeromonas salmonicida $(\mathrm{S}=0,84$ : RG= ECORI-S-3), 6) Pseudomonas maltophilia (S=0,80: RG= ECORI-S-7), 7) Aeromonas hydrophila (S=0,84: RG= ECORI-S4), 8) Pseudomonas maltophila DUP 14785, 9) Pseudomonas species DUP 16385, 10) Aeromonas hydrophila DUP 18068, 11) Aeromonas salmonicida DUP 18264, 12) Aeromonas media DUP 18578, 13) E coli DUP 3039

(S: Similarity, RG: Ribogrup)

The Riboprinter (DuPont-Qualicon, Wilmington, DE) is an automated ribotyping system that produces and analyzes ribotyping patterns of bacteria. Therefore, this method has the advantage of automation and standardization. In addition, the system reduces the time necessary to characterize or identify an organism to only $8 \mathrm{~h}$ after isolation, compared to days or even weeks for other techniques.
Aeromonas species occurred most frequently (82.53\% of the isolates) during dry seasons from June to October in the Porsuk River. A. hydrophila only recovered during autumn and winter seasons. Lower isolation frequency noticed during the spring season. It was previously reported that higher numbers of Aeromonas were recovered during summer $(6,12)$.

The presence of A. hydrophila in drinking or tap water 
should be concern for the public health. However, we have the results that there is no Aeromonas spp. in the tap and drinking water in the City of Eskisehir. In turn, the presence of Aeromonas spp. in the Porsuk River has a potential risk in terms of the residence health in the city. Because the Eskisehir tap water is as long as obtained from the Porsuk River, the health risk will be there for possible presence of Aeromonas spp in tap water. Furthermore, because of the irrigation of vegetables and watering gardens, and green places with water obtained from the Porsuk River, the potential of hazard is always there.

Wide distribution of motile Aeromonas spp. has been previously reported in the aquatic environment $(5,7,12,19$, 20, 23) and our results obtained support this finding. The present study also revealed that $76 \%$ of Aeromonas isolates exhibited beta hemolytic activity. Beta hemolysin has been reported as a virulence factor in motile aeromonads $(15,16)$.

Aeromonas species principally associated with gastroenteritis are A. caviae, A. hydrophila, and A. veronii biovar sobria. A. caviae is particularly associated with young children especially under 3 years of age. Many studies reported the isolation of several species of Aeromonas from patients with gastroenteritis which has been extensively reviewed (1, 9, 11). The health significance of detecting mesophilic aeromonads in public water supplies is not well understood: no clearly defined point-source outbreak has been documented and establishing epidemiological links is difficult. Therefore, it is thought that Riboprinter microbial characterization system may provide to get correct results in the water analysis in short time.

World Health Organization (WHO) has reported the isolation ratio of $A$. hydrophila from drinking water to be 1.0 $27 \%$ and the infectious dose to be $>10^{10}$ (4). Midilli (20) have isolated Aeromonas strains from $87.7 \%$ of environmental water samples and $40 \%$ of drinking waters in Istanbul. Mete et al. (19) have isolated eleven (2.4\%) Aeromonas strains from 449 tap water samples around the City of Denizli in Turkey. These data are quite higher than the WHO's water quality standards.

Our data meet WHO's water quality standards. However, it has been reported that Aeromonas bacteria found in municipally treated drinking water possess a wide variety of virulence-related genes (23). This finding suggests that municipally treated drinking water could be a source of potentially pathogenic Aeromonas bacteria. We have analyzed only hemolytic activities as virulence factor of our isolates. Most of them were found to be hemolytic. Actually, further studies should be done in order to detect other virulence factors.

\section{ACKNOWLEDGEMENT}

The financial support of the Research Foundation of Anadolu University is gratefully acknowledged.

\section{REFERENCES}

1. Altwegg, M.; Geiss, H.K. (1989). Aeromonas as a human pathogen. CRC Crit Rev Microbiol. 16, 253-286.

2. Boussaid, A.; Baleux, B.; Hassani, L.; Lesne, J. (1991). Aeromonas species in stabilization ponds in the arid region of Marrakesh, Marocco, and relation to faecal pollution and climatic factors. Microb. Ecol. 21, 1120.

3. Dumontet, S.; Krovacek, K.; Svenson, S.B.; Pasquale, V., Baloda, S.B.; Figureliuolo, G. (2000). Prevalence and diversity of Aeromonas and Vibrio spp. in coastal waters of Southern Italy. Comp. Immunol. Microbiol. Infect. Dis. 23, 53-72.

4. Fewtrell, L.; Bartram, J. (2001). World Health Organization (WHO): Water quality: Guidelines, Standards and Health, IWA Publishing, London.

5. Fiorentini, C.; Barbieri, E.; Falzano, L.; Matarrese, P.; Baffone, W.; Pianetti, A.; Katouli, M.; Kühn, I.; Möllby, R.; Bruscolini, F.; Casiere, A.; Doneli, G. (1998). Occurrence, diversity and pathogenicity of mesophilic Aeromonas in estuarine waters of the Italian coast of the Adriatic sea. $J$. Appl. Microbiol. 85, 501-511.

6. Gavriel, A.A.; Landre, J.P.; Lamb, A.J. (1998). Incidence of mesophilic Aeromonas within a public drinking water supply in North-East Scotland. J. Appl. Microbiol. 84, 383-392.

7. Hanninen, M.L.; Siitonen, A. (1995). Distribution of Aeromonas phenospecies among strains isolated from water, foods or from human clinical samples. Epidemiol. Infect. 115, 39-50.

8. ICMSF. (1996). Microorganisms in Foods 5: Microbiological Specifications of Pathogens. International Commission on Microbiological Specifications for Foods. Blackie Academic \& Professional, an imprint of Chapman \& Hall, New York. 
9. Janda, J.M. (1991). Recent advances in the study of the taxonomy, pathogenicity, and infectious syndromes associated with the genus Aeromonas. Clin. Microbiol. Rev., 4 (4), 397-410.

10. Janda, J.M.; Abbott, S.L. (1996). Human Pathogens In the genus Aeromonas. (B. Austin., M. Altwegg., P.J. Gosling and S. Joseph eds). Chichester, Wiley, London, United Kingdom, pp. 151-173.

11. Joseph, S.W. (1996). Aeromonas gastrointestinal disease: a case study in causation? In: Austin B et al., eds. The genus Aeromonas. London, Wiley: 311-335.

12. Kaper, J.B., Lockman, H.; Colwell, R.R. (1981). Aeromonas hydrophila: Ecology and toxigenicity of isolates from an estuary. J. Appl. Bacteriol. 50, 359-377.

13. Krovacek, K.; Pasquale, V.; Baloda, S.B.; Soprano, V.; Conte, M.; Dumontet, S. (1994). Comparison of putative virulence factors in Aeromonas hydrophila strains isolated from the marine environment and human diarrheal cases in Southern Italy. Appl. Environ. Microbiol. 60, 1379-1382.

14. Mac Faddin, J.F. (1980). Biochemical Tests for Identification of Medical Bacteria, (Williams and Wilkins Co eds.), Baltimore, USA.

15. Majeed, K.N.; Macrae, I.C. (1993). Effect of $\mathrm{pH}$ on the growth and exotoxin production by Aeromonas at refrigeration temperature. Microbios. 73, 281-288.

16. Majeed, K.N.; Macrae, I.C. (1994). Cytotoxic and haemaglutinating activities of motile Aeromonas species. J. Med. Microbiol. 40, 188-193.

17. Massa, S.; Altieri, C.; D'angela, A. (2001). The occurrence of Aeromonas spp. in natural mineral water and well water. Int. J. Food Microbiol. 63, 169-173.

18. Merino, S.; Rubires, X.; Knochel, S., Tomás, J.M. (1995). Emerging pathogens: Aeromonas spp. Int. J. Food Microbiol, 28 (2), 157-168.

19. Mete, E.; Kaleli, İ.; Demir, M.; Cevahir, N. (2002). Investigated the various water samples of Aeromonas frequency. Journal of Aknem. 16, 430-433.

20. Midilli, K. (1998). The occurence, frequency and biotyping of Aeromonas in diverse water samples collected in İstanbul. PhD thesis, Cerrahpaşa Medicine Faculty, İstanbul University, İstanbul.

21. Popoff, M.Y. (1984). Genus III. Aeromonas. In: Bergey's Manual of Systematic Bacteriology, (N.R. Kreig and J.G. Holt eds.): Williams and Wilkins, pp. 545-548.

22. Roberts, T.A.; Baird-Parker, A.C.; Tompkin. (1996). Aeromonas. In Microorganisms in Foods 5: Microbiological characteristics of food pathogens, International Commission on Microbiological Specifications for Foods. Blackie Academic \& Professional, London, pp 5-19.

23. Sen, K.; Rodgers, M. (2004). Distribution of six virulence factors in Aeromonas species isolated from US drinking water utilities: PCR identification. J. Appl. Microbiol. 97, 1077-1086.

24. Soler, L.; Figureueras, M.J.; Chacon, M.R.; Vila, J.; Marco, F.; MartinezMurcia, A.J.; Guarro, J. (2002). Potential virulence and antimicrobial susceptibility of Aeromonas popoffii recovered from freshwater and seawater. FEMS Immunol. Med. Microbiol. 32, 243-247. 